\title{
Hubungan Pelaksanaan Praktikum dan Keterampilan Generik Sains terhadap Hasil Belajar Peserta Didik
}

\section{Relationship of Practicum Implementation and Science Generic Skills to Student Learning Outcomes}

\author{
Berti Yolida $^{1}$, Ranthy Ajeng Damarwulan ${ }^{1 *}$, Darlen Sikumbang ${ }^{1}$ \\ ${ }^{1}$ Pendidikan Biologi, Fakultas Keguruan Ilmu Pendidikan Universitas Lampung \\ Jl. Prof. Dr. Soemantri Brojonegoro No.1 Bandar Lampung, Indonesia, 35145 \\ *Email Koresponden: ranthyajengdw@gmail.com
}

doi: http://dx.doi.org/10.29405/j.bes/4156-653610

Received: 10 Agustus 2019 | Accepted: 21 Desember 2019 |Published: 30 Juni 2020

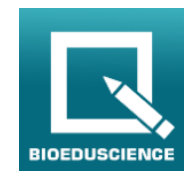

\begin{abstract}
Abstrak
Background: Penelitian ini bertujuan untuk mengetahui signifikansi hubungan antara pelaksanaan praktikum, keterampilan generik sains, dan hubungan keduanya terhadap hasil belajar peserta didik kelas X di SMAN 9 Bandar Lampung pada pembelajaran Biologi materi animalia filum Chordata. Metode: Sampel penelitian ini berjumlah 35 siswa, dipilih dengan menggunakan teknik purposive sampling. Desain yang digunakan yaitu desain deskriptif korelasional. Data penelitiannya adalah data kuantitatif dan kualitatif. Data kuantitatif berupa hasil belajar kognitif peserta didik dan data kualitatif berupa deskripsi dari hubungan pelaksanaan praktikum dan keterampilan generik sains terhadap hasil belajar peserta didik berdasarkan angket tanggapan peserta didik, wawancara kepada peserta didik, dan lembar observasi pelaksanaan praktikum. Hasil: Hasil penelitian menunjukkan terdapat hubungan yang signifikan antara pelaksanaan praktikum terhadap hasil belajar peserta didik dengan $(\mathrm{r}=0,648$; $\mathrm{p} 0,000<0,05)$, keterampilan generik sains terhadap hasil belajar peserta didik dengan $(\mathrm{r}=0,806 ; \mathrm{p} 0,000<0,05)$ serta pelaksanaan praktikum dan keterampilan generik sains terhadap hasil belajar peserta didik dengan ( sig 0,000<0,05). Kesimpulan: terdapat hubungan yang signifikan antara pelaksanaan praktikum, keterampilan generik sains, dan interaksi antara keduanya terhadap hasil belajar peserta didik
\end{abstract}

Kata kunci: Chordata, Hasil belajar, Keterampilan generik sains, Praktikum

\section{Abstract}

Background: This study aims to determine the significance of the relation between practicum implementation, generic science skills, and both of them to the learning outcomes of class X students at SMAN 9 Bandar Lampung on learning Biology of the Chordata animalia material. Methods: The sample of this study was 35 students, that selected using purposive sampling techniques. The design of this study is descriptive correlational design. The data of this study were quantitative and qualitative. Quantitative from cognitive learning outcomes and qualitative from descriptive of the relation between practicum implementation and generic science skills on students learning outcomes based on student questionnaire responses, interviews with students, and observations of practice implementation sheets. Results: The results showed that there was a significant relation between the implementation of practicum on student learning outcomes $(r=0.648 ; p$ $0,000<0.05)$, generic science skills on learning outcomes of students $(r=0.806 ; p 0,000<0.05)$ and both of them towards the learning outcomes of students (sig 0,000 <0.05). Conclusions: There was a significant relation between the implementation of practicum, generic science skills, and both of them towards student learning outcomes.

Keywords: Chordata, Learning result, Generic science skills, Practicum

Cara citasi: Yolida, B., Damarwulan R., A., \& Sikumbang, D. (2020). Hubungan Pelaksanaan Praktikum dan Keterampilan Generik Sains terhadap Hasil Belajar Peserta Didik. BIOEDUSCIENCE: Jurnal Pendidikan Biologi dan Sains. 04(01): 56-65. Doi: http://dx.doi.org/10.29405/j.bes/4156-653610 
(C) 2020 Oleh Bioeduscience: Jurnal Pendidikan Biologi dan Sains, Uhamka, Jakarta. Artikel ini bersifat open access yang didistribusikan di bawah syarat dan ketentuan Creative Commons Attribution (CC-BY) license. (http://creativecommons.org/licenses/by/4.0/).

\section{PENDAHULUAN}

Pendidikan di era globalisasi saat ini merupakan suatu tantangan bagi anak bangsa dan setiap negara untuk dapat menciptakan generasi yang memperkuat landasan di segala sektor kehidupan.Kondisi tersebut mendorong suatu negara untuk dapat menghasilkan sumber daya manusia yang berkualitas. Upaya untuk meningkatkan sumber daya manusia yang berkualitas dapat melalui banyak hal, salah satunya adalah dengan meningkatkan mutu pendidikan.

Faktanya, berdasarkan hasil penelitian (Muslam, 2011) yang mengatakan bahwa pendidikan memiliki keterkaitan erat dengan globalisasi. Salah satunya di Indonesia. Dalam menuju era globalisasi, Indonesia harus melakukan reformasi dalam proses pendidikan, dengan tekanan menciptakan sistem pendidikan yang lebih komprehensif dan fleksibel, sehingga para lulusan dapat berfungsi secara efektif dalam segala sektor kehidupan. Oleh karena itu, pendidikan di Indonesia harus dirancang sedemikian rupa agar para peserta didik dapat mengembangkan potensi yang dimiliki secara alami dan kreatif dalam mengembangkan pendidikan yang berwawasan global.

Pendidikan, khususnya di Sekolah Menengah Atas (SMA) banyak mata pelajaran yang wajib dipelajari oleh peserta didik, salah satu mata pelajaran yang wajib tersebut adalah biologi. Biologi merupakan bidang sains yang mempelajari kehidupan (Campbell \& Reece, 2008). Berdasarkan hakikat biologi sebagai sains yang mengacu pada 3 hal yaitu proses, produk, dan sikap, maka biologi dapat membantu kita dalam menyelesaikan segala persoalan seharihari, baik dalam lingkungan sekitar hingga lingkup lingkungan yang luas, sehingga biologi dapat diterapkan dalam berbagai aspek kehidupan.

Aspek kehidupan dapat berupa kecakapan akademik. Kecakapan akademik peserta didik dapat dilatih melalui pembelajaran. Salah satunya yaitu dengan pembelajaran biologi. Pembelajaran biologi merupakan suatu proses untuk menghantarkan peserta didik ke tujuan belajarnya, dan biologi sendiri berperan sebagai alat untuk mencapai tujuan tersebut. Oleh karena itu, pembelajaran biologi dapat dipelajari melalui pendekatan kontekstual. Pada pembelajaran dengan pendekatan kontekstual, peserta didik dibiasakan untuk memecahkan masalahnya sendiri, menemukan ide-ide yang dapat mengembangkan pola pikir peserta didik. Seperti pendapat (Kusmiyati, 2009) mengatakan bahwa pembelajaran dengan penemuan merupakan suatu komponen penting dalam pendekatan kontruktivis, peserta didik didorong untuk belajar melalui keterlibatan aktif mereka sendiri dengan konsep-konsep dan prinsip-prinsip, dan pendidik mendorong peserta didik untuk memiliki pengalaman dan melakukan percobaan yang memungkinkan mereka menemukan prinsip untuk dirinya sendiri.

Kegiatan melakukan percobaan atau praktikum sangat dimungkinkan adanya penerapan beragam keterampilan proses. Salah satunya yaitu Keterampilan Generik Sains. KGS ini merupakan kemampuan berpikir peserta didik dan bertindak mengembangkan keterampilan berdasarkan pengetahuan yang dimiliki individu. Hal ini didukung oleh pendapat (Brotosiswoyo, 2000), keterampilan generik sains adalah keterampilan yang dapat digunakan untuk mempelajari berbagai konsep dan menyelesaikan berbagai masalah sains. Dalam satu kegiatan ilmiah, misalnya kegiatan memahami konsep, terdiri dari beberapa kompetensi generik. Kegiatan-kegiatan ilmiah yang berbeda dapat mengandung kompetensi-kompetensi generik yang sama. Ciri dari pembelajaran sains melalui keterampilan generik sains adalah membekalkan keterampilan generik sains kepada peserta didik sebagai pengembangan keterampilan berpikir 
tingkat tinggi. Menurut (Brotosiswoyo, 2000) keterampilan generik sains dalam pembelajaran IPA dapat dikategorikan menjadi 9 indikator yaitu: (1) pengamatan langsung (direct observation); (2) pengamatan tak langsung (indirect observation); (3) kesadaran tentang skala besaran (sense of scale); (4) bahasa simbolik (symbolic languange); (5) kerangka logika taatasas (logical self-consistency) dari hukum alam; (6) inferensi logika; (7) hukum sebab akibat (causality); (8) pemodelan matematika (mathematical modeling); (9) membangun konsep (concept formation).

Berdasarkan hasil wawancara yang dilakukan peneliti terhadap guru biologi di SMA Negeri 9 Bandar Lampung pada tanggal 16 Oktober 2018, keadaan di lapangan menunjukkan bahwa materi animalia biasanya diajarkan dengan menggunakan metode ceramah. Hal ini dikarenakan menurut pendidik dengan menggunakan metode ceramah saja, peserta didik sudah mampu mengerti dan memahami materi animalia pada filum Chordata ini. Seharusnya dalam proses pembelajaran khususnya pada materi ini sangat diperlukan sebuah praktikum yang dapat melibatkan peserta didik untuk aktif secara langsung. Karena pada materi animalia ini, cakupan bahasannya sangat banyak sehingga akan lebih efektif dan efisien jika peserta didik dapat mempelajari secara langsung mengenai materi animalia ini, tidak hanya dengan metode ceramah saja, dengan mempelajarinya secara langsung, maka peserta didik dapat mengetahui langsung klasifikasi hewan berdasarkan morfologi dan anatomi melalui metode praktikum. Dengan melakukan praktikum peserta didik dapat mengembangkan secara mandiri prosesnya sehingga dirinya lebih mampu mengingat dan memahami suatu konsep.

Hal ini diperkuat oleh pernyataan (Zainuddin, 2001) praktikum adalah salah satu bentuk pengajaran yang cukup efektif dan sudah meliputi tiga ranah yaitu ranah kognitif, afektif, dan psikomotorik. Praktikum akan benar-benar efektif jika dalam desainnya terstruktur dan eksplisit adanya pelatihan dari ketiga ranah tersebut.

Terkait dengan keterampilan praktikum, praktikum dapat melatih peserta didik dalam mengembangkan kemampuan sainnya melalui keterampilan sains, salah satunya yaitu Keterampilan Generik Sains (KGS), berdasarkan hasil penelitian terdahulu yang pernah dilakukan oleh (Agustinaningsih, W., Sarwanto \& Suparmi, 2014) terkait pengembangan keterampilan generik sains menyatakan bahwa peserta didik dapat berubah dari pembelajar pasif menjadi pembelajar aktif denganpenerapan diskusi informasi sehingga peserta didik dapat berbagi ide dan pemikiran dalam proses pembelajaran.

Penelitian ini bertujuan untuk mengetahui hubungan pelaksanaan praktikum, keterampilan generik sains dan hubungan keduanya terhadap hasil belajar peserta didik kelas X di SMAN 9 Bandar Lampung pada pembelajaran biologi materi animalia filum Chordata.

\section{MATERI DAN METODE}

Penelitian ini bertempat di SMA Negeri 9 Bandar Lampung yang beralamat di jalan Panglima Polem No. 18 Segala Mider, Kota Bandar Lampung. Penelitian ini dilaksanakan pada semester genap tahun pelajaran 2018/2019 yaitu pada bulan April 2019.

Populasi dalam penelitian ini adalah seluruh peserta didik kelas X IPA SMA Negeri 9 Bandar Lampung tahun pelajaran 2018/2019 yang berjumlah 360 peserta didik dari 10 kelas. Sampel yang dilakukan dalam penelitian ini adalah siswa kelas X IPA 5 dengan jumlah 35 peserta didik.

Teknik pengambilan sampel pada penelitian ini dengan menggunakan teknik purposive sampling yaitu teknik dimana peneliti menentukan pengambilan sampel dengan cara menetapkan ciri-ciri khusus yang sesuai dengan tujuan penelitian. Ciri-ciri khusus yang digunakan peneliti untuk menetapkan sampel yaitu apabila kelas tersebut sudah mempelajari materi animalia filum Chordata. Alasannya ditetapkan kriteria tersebut adalah jika peserta didik sudah mempelajari materi animalia filum Chordata, 
maka peserta didik dapat dengan mudah memahami dan menerapkan secara langsung teori yang telah dipelajari ke dalam praktikum.

Penelitian ini mengunakan desain deskriptif korelasional. Desain ini digunakan untuk mendapatkan informasi tentang suatu gejala pada saat penelitian. Dalam desain ini, peneliti tidak melakukan manipulasi perlakuan atau penempatan subjek, akan tetapi diarahkan untuk menetapkan sifat suatu situasi pada waktu penyelidikan itu dilakukan. Tujuannya adalah untuk melukiskan variabel atau kondisi apa yang ada dalam suatu situasi. Fokus desain ini menggunakan studi korelasi yang berfungsi untuk mengukur terhadap besarnya hubungan antara variabel-variabel. Dalam pelaksanaannya desain deskriptif korelasional ini menggunakan teknik analisis statistik korelasi. Peneliti memastikan sejauh mana perbedaan di salah satu variabel ada hubungannya dengan perbedaan dalam variabel yang lain. Jadi, penelitian korelasional ini bertujuan untuk mengetahui hubungan antara tiga variabel yaitu pelaksanaan praktikum (X1) dan keterampilan generik sains peserta didik (X2), sebagai variabel bebas dan hasil belajar peserta didik (Y) sebagai variabel terikat.

\section{Pengumpulan Data dan Analisis Data}

Jenis data yang digunakan dalam penelitian ini adalah data kuantitatif dan data kualitatif. Data kuantitatif pada penelitian ini diperoleh dari hasil belajar kognitif peserta didik yang berupa ulangan harian. Data kualitatif pada penelitian ini adalah berupa deskripsi dari hubungan pelaksanaan praktikum dan keterampilan generik sains terhadap hasil belajar peserta didik berdasarkan angket tanggapan peserta didik dalam bentuk skala likert, wawancara tertutup kepada peserta didik yang dianalisis secara deskriptif dengan menggunakan teknik analisis data model Milles dan Huberman. Daftar pertanyaan wawancara kepada peserta didik terdiri dari 16 pertanyaan. Serta lembar observasi pelaksanaan praktikum dengan indikator yang diamati sebanyak 20 pernyataan dan keterampilan generik sains dengan Indikator yang diamati sebanyak 4 pernyataan.
Jenis teknik pengambilan data yang digunakan dalam penelitian ini adalah teknik triangulasi instrumen. Teknik ini menggunakan beberapa instrumen untuk digabungkan menjadi sebuah data dalam penelitian. Teknik pengambilan data yang digunakan pada penelitian ini sebagai berikut: angket, wawancara, lembar observasi, dan hasil belajar kognitif peserta didik.

Teknik analisis data pada penelitian ini dengan menggunakan teknik analisis korelasi dengan bantuan SPSS 17.0. Teknik analisis korelasi menggunakan dua uji yaitu uji normalitas dan uji hipotesis. Uji hipotesis pertama dan kedua menggunakan teknik uji korelasi Product Moment Pearson. Uji ini berfungsi untuk mengetahui hubungan antara dua variabel penelitian, yaitu hubungan pelaksanaan praktikum (X1) terhadap hasil belajar peserta didik (Y) dan hubungan keterampilan generik sains (X2) terhadap hasil belajar (Y). Sedangkan uji hipotesis ketiga menggunakan teknik korelasi regresi ganda. Uji regresi ganda ini berfungsi untuk mengetahui hubungan antara ketiga variabel penelitian.

\section{HASIL}

\section{Pelaksanaan Praktikum}

Hasil persentase tanggapan peserta didik terhadap pelaksanaan praktikum. Persentase tanggapan tersebut menunjukkan bahwa rata-rata kategori sangat baik, merujuk pada Tabel 1.

Tabel 1. Persentase Tanggapan Peserta Didik terhadap Pelaksanaan Praktikum

\begin{tabular}{|c|c|c|c|}
\hline No & Frekuensi & $\begin{array}{c}\text { Persentase } \\
(\%)\end{array}$ & Kategori \\
\hline 1 & 30 & 85,71 & $\begin{array}{c}\text { Sangat } \\
\text { Baik }\end{array}$ \\
\hline 2 & 5 & 14,28 & Baik \\
\hline 3 & 0 & 0 & $\begin{array}{c}\text { Cukup } \\
\text { Baik }\end{array}$ \\
\hline 4 & 0 & 0 & $\begin{array}{c}\text { Kurang } \\
\text { Baik } \\
\text { Sangat }\end{array}$ \\
\hline 5 & 0 & 0 & $\begin{array}{c}\text { Kurang } \\
\text { Baik }\end{array}$ \\
\hline
\end{tabular}


Diketahui dari hasil persentase tanggapan peserta didik terhadap pelaksanaan praktikum pada Tabel 1 menunjukkan bahwa persentase tanggapan terbesar yaitu berada dalam kategori sangat baik dengan persentase sebesar $85,71 \%$ dan persentase tanggapan terendah terdapat pada kategori baik dengan persentase sebesar 14,28\%. Hal ini didukung oleh rata-rata persentase dari kelima deskripsi aspek pelaksanaan praktikum, merujuk pada Gambar 1.

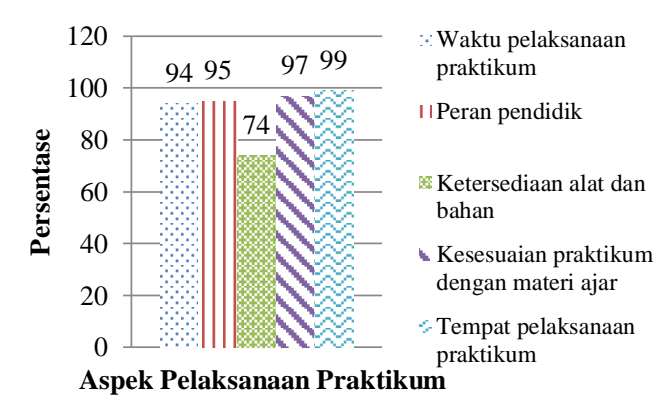

Gambar 1. Grafik Tanggapan Pelaksanaan Praktikum pada Lima Aspek Indikator

Dilihat dari hasil persentase kelima deskripsi aspek pelaksanaan praktikum tersebut, indikator tertinggi yaitu pada aspek tempat pelaksanaan praktikum dengan persentase sebesar $99 \%$, sedangkan indikator terendah yaitu pada aspek ketersediaan alat dan bahan dengan persentase sebesar $74 \%$.

\section{Keterampilan Generik Sains}

Diperoleh dari hasil persentase tanggapan peserta didik terhadap pelaksanaan praktikum yang memunculkan keterampilan generik sains menunjukkan bahwa rata-rata kategori sangat baik, merujuk pada Tabel 2 .

Tabel 2. Persentase Tanggapan Pelaksanaan Praktikum yang Memunculkan Keterampilan Generik Sains

\begin{tabular}{|c|c|c|c|}
\hline No & Frekuensi & $\begin{array}{c}\text { Persentase } \\
(\%)\end{array}$ & Kategori \\
\hline 1 & 18 & 51,42 & $\begin{array}{l}\text { Sangat } \\
\text { Baik }\end{array}$ \\
\hline 2 & 11 & 31,42 & Baik \\
\hline 3 & 6 & 17,14 & $\begin{array}{l}\text { Cukup } \\
\text { Baik }\end{array}$ \\
\hline 4 & 0 & 0 & $\begin{array}{c}\text { Kurang } \\
\text { Baik } \\
\text { Sangat }\end{array}$ \\
\hline 5 & 0 & 0 & $\begin{array}{c}\text { Kurang } \\
\text { Baik }\end{array}$ \\
\hline
\end{tabular}

Hasil persentase tanggapan peserta didik terhadap pelaksanaan praktikum yang memunculkan keterampilan generik sains pada

Tabel 3. Rekapitulasi Keterampilan Generik Sains berdasarkan Lembar Observasi

\begin{tabular}{cccc}
\hline $\begin{array}{c}\text { Keterampilan } \\
\text { Generik }\end{array}$ & Cakupan Keterampilan Generik & $\begin{array}{c}\text { Persentase } \\
(\%)\end{array}$ & Kriteria \\
\hline $\begin{array}{c}\text { Pengamatan } \\
\text { Langsung }\end{array}$ & $\begin{array}{c}\text { Mengamati objek yang karakteristiknya dapat } \\
\text { diobservasi langsung oleh indera baik } \\
\text { menggunakan alat maupun tidak }\end{array}$ & 92,85 & $\begin{array}{c}\text { Sangat } \\
\text { Baik }\end{array}$ \\
$\begin{array}{c}\text { Pengamatan Tak } \\
\text { Langsung }\end{array}$ & $\begin{array}{c}\text { Mengamati objek yang karakteristiknya tidak dapat } \\
\text { diobservasi langsung oleh indera tapi efeknya yang } \\
\text { terobservasi dengan alat melalui proses } \\
\text { Membuat objek, aktivitas, atau tiruan yang dapat } \\
\text { digunakan sebagai contoh. }\end{array}$ & 73,57 & Baik \\
Pemodelan & $\begin{array}{c}\text { Melakukan Pengamatan atau aktivitas tertentu } \\
\text { untuk dicontoh }\end{array}$ & 85,71 & Baik \\
\hline & Rata-rata Keseluruhan $\bar{X} \pm$ Sd & $80,88 \pm 8,52$ & Baik \\
\hline
\end{tabular}


Tabel 3. Menunjukkan bahwa persentase skor tertinggi terdapat pada cakupan pengamatan langsung dengan persentase sebesar 92,85 \% yang berkriteria sangat baik, sedangkan persentase skor terendah pada cakupan pengamatan tak langsung dengan persentase sebesar $73,57 \%$ yang berkriteria baik. Berdasarkan Tabel 3. Diketahui bahwa persentase rata-rata keseluruhan rekapitulasi keterampilan generik sains berdasarkan lembar observasi yaitu sebesar 80,88\% dengan kriteria baik.

\section{Hasil Belajar}

Tabel 4. Distribusi Hasil Belajar Kognitif Peserta Didik

\begin{tabular}{cccc}
\hline No & Frekuensi & $\begin{array}{c}\text { Persentase } \\
(\%)\end{array}$ & Kategori \\
\hline 1 & 18 & 54,3 & $\begin{array}{c}\text { Sangat } \\
\text { Tinggi }\end{array}$ \\
2 & 14 & 37 & Tinggi \\
3 & 0 & 8,6 & Cukup \\
4 & 0 & 0 & Rendah \\
5 & 0 & 0 & $\begin{array}{c}\text { Sangat } \\
\text { Rendah }\end{array}$ \\
\hline
\end{tabular}

Diketahui dari hasil persentase distribusi hasil belajar kognitif peserta didik pada Tabel 4 menunjukkan bahwa persentase distribusi terbesar yaitu berada dalam kategori sangat tinggi dengan persentase sebesar 54,3\% dan persentase distribusi terendah terdapat pada kategori cukup dengan persentase sebesar 8,6 $\%$. Hal ini didukung oleh rata-rata persentase C1-C6 pada ranah kognitif, merujuk pada Gambar 2.

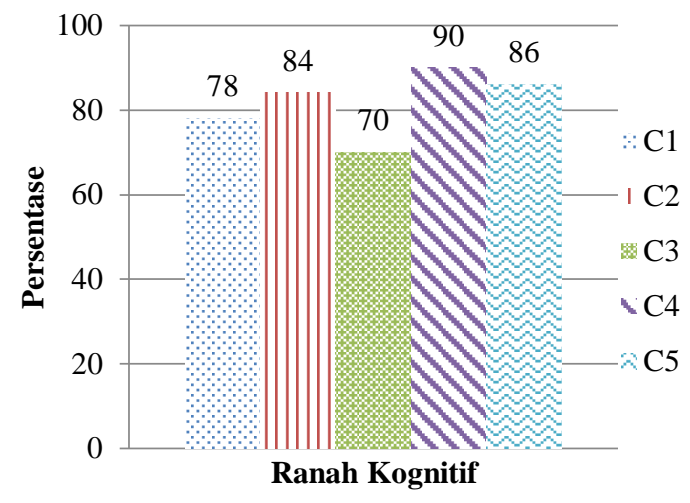

Gambar 2. Grafik Hasil Belajar Kognitif Peserta Didik

\section{Pengajuan Hipotesis}

Pengujian hipotesis ini berfungsi untuk mengetahui hubungan antara kedua variabel yaitu variabel bebas dan terikat. Teknik analisis yang digunakan dalam penelitian pengujian hipotesis ini yaitu teknik analisis korelasi Produk Moment yang dihitung dengan menggunakan SPSS versi 17 for windows, teknik ini berfungsi untuk menguji hipotesis pertama dan hipotesis kedua. Sedangkan untuk menguji hipotesis ketiga yaitu menggunakan teknik analisis korelasi ganda. Adapun hasil perhitungan korelasi Produk Moment pada hipotesis pertama dan hipotesis kedua yang disajikan dalam tabel berikut:

Tabel 5. Ringkasan Hasil Korelasi Produk Moment

\begin{tabular}{ccccc}
\hline \multicolumn{2}{c}{ Variabel } & Terikat & Signifikansi & Keterangan \\
\hline Bebas & T & thitung $(2,126)>\mathrm{t}$ tabel \\
$\mathrm{X}_{1}$ & $\mathrm{Y}$ & 0,648 & $\begin{array}{c}\text { Positif, signifikan- } \\
\text { kekuatan hubungan } \\
\text { kuat }\end{array}$ \\
& & & $(1,692)$ & $\begin{array}{c}\text { Positif, signifikan- } \\
\text { kekuatan hubungan } \\
\text { sangat kuat }\end{array}$ \\
\hline
\end{tabular}

\section{Uji Hipotesis Pertama}

Hasil analisis data diatas menunjukkan bahwa angka korelasi Produk Moment antara pelaksanaan praktikum terhadap hasil belajar peserta didik sebesar 0,648 ( $\mathrm{r}$ hitung), nilai koefisien korelasi menunjukkan hubungan positif yang artinya terdapat hubungan yang 
yang kuat antara pelaksanaan praktikum terhadap hasil belajar peserta didik. Kemudian, nilai $\mathrm{t}$ hitung $(2,126)>\mathrm{t}$ tabel $(1,692)$ yang berarti menunjukkan bahwa antara pelaksanaan praktikum terhadap hasil belajar peserta didik terdapat hubungan yang signifikan antara keduaanya.

\section{Uji Hipotesis Kedua}

Hasil analisis data diatas menunjukkan bahwa angka korelasi Produk Moment antara

keterampilan generik sains terhadap hasil belajar peserta didik sebesar 0,806 ( $\mathrm{r}$ hitung), nilai koefisien korelasi menunjukkan hubungan positif yang artinya terdapat hubungan yang yang sangat kuat antara pelaksanaan praktikum terhadap hasil belajar peserta didik. Kemudian, nilai $\mathrm{t}$ hitung $(5,331)>\mathrm{t}$ tabel $(1,692)$ yang berarti menunjukkan bahwa antara keterampilan generik sains terhadap hasil belajar peserta didik terdapat hubungan yang signifikan antara keduanya.

Tabel 6. Ringkasan Hasil Regresi Ganda

\begin{tabular}{cccccccc}
\hline Variansi & Konstanta & $\begin{array}{c}\text { Koefisien } \\
\text { Korelasi }\end{array}$ & $\mathrm{R}^{2}$ & $\begin{array}{c}\mathrm{F} \\
\text { Hitung }\end{array}$ & $\begin{array}{c}\mathrm{F} \\
\text { Tabel }\end{array}$ & $\begin{array}{c}\text { Sig } \\
\text { Regresi }\end{array}$ & $\begin{array}{c}\text { Persamaan } \\
\text { Regresi }\end{array}$ \\
\hline $\begin{array}{c}\text { Konstanta } \\
0,745\end{array}$ & & & & & & $\mathrm{Y}=0,745+$ \\
$\mathrm{X}_{1}$ & 0,262 & 0,832 & 0,693 & 36,102 & 4,14 & 0,000 & $0,262 \mathrm{X}_{1}+$ \\
$\mathrm{X}_{2}$ & 0,649 & & & & & & $0,649 \mathrm{X}_{2}$ \\
\hline
\end{tabular}

Hasil uji regresi diperoleh persamaan regresi yaitu $\mathrm{Y}=0,745+0,262 \mathrm{X} 1+0,649 \mathrm{X} 2$, artinya jika siswa tidak mengikuti pelaksanaan praktikum dan tidak memunculkan keterampilan generik sains maka peserta didik memperoleh hasil belajar sebesar 0,745 . Koefisien regresi sebesar 0,262 menunjukkan jika siswa mengikuti pelaksanaan praktikum akan meningkatkan hasil belajar sebesar 0,262.

Uji korelasi ganda digunakan untuk mengetahui tingkat dan hubungan pelaksanaan praktikum dan keterampilan generik sains terhadap hasil belajar peserta didik. Diperoleh F hitung 36,102, maka pada taraf signifikan $5 \%$ diperoleh $\mathrm{F}$ tabel sebesar 4,14. Artinya $\mathrm{F}$ hitung $(36,102)>F$ tabel $(4,14)$ maka terdapat hubungan yang signifikan antara pelaksanaan praktikum dan keterampilan generik sains terhadap hasil belajar peserta didik. Nilai koefisien korelasi 0,832 menunjukan bahwa tingkat hubungan antara pelaksanaan praktikum dan keterampilan generik sains terhadap hasil belajar peserta didik sangat kuat. Koefisien korelasi ganda menunjukkan tanda $(+)$ yang berarti ada hubungan yang positif. Nilai koefisien determinasi $\mathrm{R}$ square sebesar 0,693 menunjukkan bahwa 69,3\% hasil belajar peserta didik dipengaruhi secara bersama-sama oleh pelaksanaan praktikum dan keterampilan generik sains, sedangkan 30,7\% dipengaruhi oleh faktor lain, tetapi tidak diperhitungkan dalam penelitian ini.

\section{PEMBAHASAN}

Berdasarkan hasil analisis persentase tanggapan peserta didik terhadap pelaksanaan praktikum menunjukkan bahwa rata-rata kategori sangat baik, merujuk pada Tabel 1. Hal ini didukung oleh rata-rata persentase dari kelima deskripsi aspek pelaksanaan praktikum, merujuk pada Gambar 1. Dilihat dari hasil persentase kelima deskripsi aspek pelaksanaan praktikum tersebut, indikator tertinggi yaitu pada aspek tempat pelaksanaan praktikum dengan persentase sebesar $99 \%$, sedangkan indikator terendah yaitu pada aspek ketersediaan alat dan bahan dengan persentase sebesar 74\%. Dari hal tersebut diketahui bahwa tempat pelaksanaan praktikum mendapatkan persentase terbesar, oleh karena itu, tempat pelaksanaan praktikum sangat mempengaruhi kegiatan praktikum pada materi animalia filum Chordata yang dilakukan oleh peserta didik. Pelaksanaan praktikum pada materi animalia 
filum Chordata dilakukan di laboratorium Biologi.

Sesuai dengan pendapat (Wirjosoemarto, 2004) Laboratorium adalah sebagai suatu ruangan atau tempat untuk melakukan percobaan atau penelitian. Dalam pembelajaran Biologi, laboratorium dapat juga berupa terbuka misalnya kebun botani, kandang, dan hewan. Laboratorium juga dapat diartikan sebagai tempat subjek belajar melakukan eksperimeneksperimen ilmiah. Sedangkan indikator terendah yaitu pada aspek ketersediaan alat dan bahan dengan persentase sebesar 74\%. Hal ini disebabkan karena terjadi kendala yaitu terdapat bahan yang kurang saat akan digunakan untuk kegiatan praktikum. Bahan tersebut yaitu kloroform, persediaan kloroform dilaboraturium sangat terbatas. Sehingga dengan menggunakan satu wadah untuk membius hewannya, perlakuan tersebut kurang efektif dan efisien. Oleh karena itu, ketersediaan alat dan bahan juga dapat mempengaruhi pelaksanaan praktikum, karena alat dan bahan merupakan komponen utama yang sangat menunjang dalam kegiatan praktikum, jika alat dan bahan yang akan digunakan untuk praktikum tidak tersedia, maka praktikum tidak dapat berjalan dengan baik.

Hal ini diperkuat dengan pendapat yang dikemukakan oleh (Indrawan, 2015) menyatakan bahwa peralatan yang terdapat dalam ruang laboratorium diharapkan memiliki kelengkapan yang lengkap dan kualitas yang bagus, baik dalam hal alat maupun bahannya, karena sangat penting dalam menunjang kelancaran proses kegiatan praktikum.

Hasil analisis persentase tanggapan peserta didik terhadap pelaksanaan praktikum yang memunculkan keterampilan generik sains menunjukkan bahwa rata-rata kategori sangat baik, merujuk pada Tabel 2. Hal ini didukung oleh rata-rata persentase dari kelima deskripsi aspek pelaksanaan praktikum. Dilihat dari hasil persentase kelima deskripsi aspek pelaksanaan praktikum tersebut, indikator tertinggi yaitu pada aspek pengamatan langsung dengan persentase sebesar $100 \%$, sedangkan indikator terendah yaitu pada aspek pemodelan dengan persentase sebesar $67 \%$ yang merujuk pada Gambar 2.

Dilihat dari hal tersebut diketahui bahwa peserta didik lebih menonjolkan pengamatan langsung dalam memunculkan keterampilan generik sains pada saat pelaksanaan praktikum materi animalia filum Chordata.Sesuai dengan pendapat (Liliasari, 2007) pengamatan langsung merupakan kegiatan yang dapat diartikan dan ditangkap baik oleh alat indera manusia.Contohnya yaitu ketika membedah mencit, dapat dilakukan pengamatan secara langsung morfologi dan anatomi dengan melihat dan membedah langsung mencitnya. Oleh karena itu, peserta didik dapat lebih mudah memunculkan keterampilan generik sains pada pengamatan langsung, dibandingkan dengan memunculkan keterampilan generik sains pada pengamatan tak langsung, sebab akibat, pemodelan, dan inferensi.

Dilihat dari Gambar 2 diketahui bahwa indikator terendah yaitu pada aspek pemodelan dengan persentase sebesar $67 \%$, hal ini dikarenakan peserta didik kurang menguasai konsep dasar pada materi animalia filum Chordata. Penelitian ini sesuai dengan penelitian yang dilakukan oleh (Yuliyanti \& Hasan, 2016) yang menyatakan bahwa penguasaan keterampilan generik sains yang terendah adalah pada aspek pemodelan sebesar $32,5 \%$ dengan kategori sedang, hal ini dikarenakan kurangnya penguasaan konsep dasar, sehingga mengalami kesulitan dalam menyelesaikan soal.

Selain itu, untuk mengetahui keterampilan generik sains yang dimiliki tiap individu peserta didik, peneliti menilai melalui lembar observasi yang di lakukan oleh para observer dan rekapitulasi keterampilan generik sains berdasarkan lembar observasi pada Tabel 3 dan memberikan Lembar Kerja Peserta Didik (LKPD). Lembar observasi digunakan untuk menilai keterampilan generik sains tiap individu 
pada pelaksanaan praktikum dengan melihat apakah individu tersebut dapat memunculkan lima aspek keterampilan generik sains yang akan dinilai oleh observer. Lima aspek itu diantaranya pengamatan langsung, pengamatan tak langsung, sebab akibat, pemodelan, dan inferensi.

Hasil rekapitulasi keterampilan generik sains berdasarkan lembar observasi yang merujuk pada Tabel 3, diperoleh hasil yaitu aspek tertinggi terdapat pada aspek pengamatan langsung dengan persentase sebesar 92,85\% dan persentase terendah yaitu terdapat pada aspek pengamatan tak langsung dengan persentase sebesar $73,57 \%$.

Sedangkan tujuan peneliti memberikan LKPD terhadap peserta didik fungsi nya untuk membantu peserta didik dalam memahami konsep, karena dengan mengerjakan LKPD secara berdisukusi dan berkelompok maka siswa yang memiliki keterampilan generik sains yang rendah dapat membantu peserta didik tersebut dalam memahami konsep dengan baik dan akan memperoleh hasil belajar yang baik. Hal ini didukung dengan pendapat yang dikemukakan oleh (Hasan, 2016) menyatakan bahwa pembelajaran yang menggunakan LKPD dapat meningkatkan pemahaman konsep peserta didik.

Hasil persentase distribusi frekuensi hasil belajar peserta didik dapat dilihat pada Tabel 4 yang berfungsi untuk mengetahui pengetahuan peserta didik tentang materi animalia filum Chordata. Setelah dilakukan analisis dari hasil data yang diperoleh, terlihat persentase tertinggi pada distribusi hasil belajar peserta didik terdapat dalam kategori sangat tinggi yaitu persentasenya sebesar $54,3 \%$ dengan jumlah frekuensi sebanyak 18, sedangkan persentase terendah terdapat dalam kategori cukup dengan persentase sebesar 8,6 \%. Dari persentase distribusi frekuensi hasil belajar peserta didik tersebut diketahui bahwa rata-rata tingkatan kemampuan kognitif peserta didik tentang materi animalia filum Chordata sangat tinggi. Di dalam hasil belajar peserta didik terdapat deskripsi ranah kognitif yang diperoleh dari persentase C1-C6 pada setiap soal.Hasil analisisnya ditampilkan dalam bentuk grafik yang disajikan dalam Gambar 3 dan didapatkan bahwa pembelajaran mengenai filum chordata memiliki hasil pada persentase $\mathrm{C} 4$ lebih tinggi. Hal ini dapat dilihat bahwa kemampuan peserta didik terhadap proses dalam menemukan suatu konsep mampu dilakukan dengan baik dalam mengembangkan kemampuan berpikir secara kritis berdasarkan informasi-informasi yang diberikan oleh pendidik melalui kegiatan mengamati, merumuskan hipotesis, menyelidiki dan menganalisis (Rizal \& Danial, 2014).

Hal ini diperkuat dengan pendapat yang dikemukakan oleh Taksonomi Bloom dalam (Daryanto, 2013) menyatakan bahwa aspek kognitif dibedakan atas enam jenjang yakni: pengetahuan, pemahaman, penerapan, analisis, sintesis, dan penilaian. Keenam aspek ini saling berhubungan atau tumpang tindih, dimana aspek yang lebih tinggi meliputi semua aspek yang ada dibawahnya. Jadi, untuk menuju aspek kognitif yang lebih tinggi siswa harus sudah mampu atau sudah melewati aspek kognitif yang sebelumnya. Seperti halnya siswa bisa memahami suatu materi maka terlebih dahulu siswa harus mempunyai pengetahuan dasar tentang materi tersebut.

Hasil penelitian pada hipotesis pertama menunjukan bahwa terdapat hubungan yang positif dan signifikan antara pelaksanaan praktikum (X1) terhadap hasil belajar peserta didik (Y) kelas X IPA 5 di SMA Negeri 9 Bandar Lampung pada materi animalia filum Chordata. Hal ini diketahui dari hasil analisis uji hipotesis pertama pada Tabel 5 dengan menggunakan korelasi product moment yang memperoleh nilai koefisien korelasi $\mathrm{r}$ hitung sebesar 0,648. Koefisien korelasi filum Chordata menunjukan angka positif yang berarti bahwa terdapat hubungan. Hubungan yang terdapat dalam koefisean korelasi ini termasuk dalam kategori kuat antara pelaksanaan praktikum (X1) terhadap hasil belajar peserta didik (Y). 
Hasil penelitian pada hipotesis kedua menunjukan bahwa terdapat hubungan yang positif dan signifikan antara keterampilan generik sains (X2) terhadap hasil belajar peserta didik (Y) kelas X IPA 5 di SMA Negeri 9 Bandar Lampung pada materi animalia filum Chordata.

Hal ini diketahui dari hasil analisis uji hipotesis kedua pada Tabel 5 dengan menggunakan korelasi product moment yang memperoleh nilai koefisien korelasi $\mathrm{r}$ hitung sebesar 0,806. Koefisien korelasi menunjukan angka positif yang berarti bahwa terdapat hubungan. Hubungan yang terdapat dalam koefisien korelasi ini termasuk dalam kategori sangat kuat antara keterampilan generik sains (X2) terhadap hasil belajar peserta didik (Y).

Dilihat dari hasil penelitian pada hipotesis ketiga menunjukan bahwa terdapat hubungan yang positif dan signifikan dengan kekuatan hubungan kuat antara hubungan pelaksanaan praktikum (X1) dan keterampilan generik sains (X2) terhadap hasil belajar peserta didik (Y) kelas X IPA 5 di SMA Negeri 9 Bandar Lampung pada materi animalia filum Chordata dengan persentase hubungannya sebesar $69,3 \%$.

\section{KESIMPULAN}

Penelitian ini dapat disimpulkan bahwa terdapat hubungan yang signifikan antara pelaksanaan praktikum, keterampilan generik sains, dan interaksi antara keduanya terhadap hasil belajar peserta didik kelas $\mathrm{X}$ di SMAN 9 Bandar Lampung pada materi animalia filum Chordata tahun pelajaran 2018/2019.

\section{REFERENSI}

Agustinaningsih, W., Sarwanto, \& Suparmi. (2014). Pengembangan Instruksi Praktikum Berbasis Keterampilan Generik Sains Pada Pembelajaran Fisika Materi Teori Kinetik Gas Kelas XI IPA SMA Negeri 8 Surakarta Tahun Ajaran 2012/2013. Jurnal Inkuiri, 3(1), 50-61.

Brotosiswoyo, B. . (2000). Kiat Pembelajaran MIPA dan Kiat Pembelajaran Fisika di Perguruan Tinggi (Departemen). Jakarta.

Campbell, N. A., \& Reece, J. B. (2008). Biologi Edisi Kedelapan Jilid 2. Jakarta: Erlangga.
Daryanto. (2013). Inovasi Pembelajaran Efektiv. Bandung: Yrma Widya.

Hasan, M. (2016). Pengembangan Lembar Kegiatan Peserta Didik (Lkpd) Berbasis Masalah Untuk Meningkatkan Pemahaman Konsep Dan Aktivitas Belajar Peserta Didik Pada Materi Larutan Penyangga. Jurnal Pendidikan Sains Indonesia, 4(1).

Indrawan, I. (2015). Pengantar Manajemen Sarana dan Prasarana Sekolah. Yogyakarta: Deepublished.

Kusmiyati, K. (2009). Pendekatan Kontekstual dalam Pembelajaran Ipa(Biologi) Di Sekolah Menengah Pertama. Jurnal Pijar Mipa, 4(1). https://doi.org/https://doi.org/10.29303/jpm.v4i1 .178

Liliasari. (2007). Sciencetific Concept and Generic Science Skill Relationship in the 21 th Century Science Education. In Makalah Kunci pada Seminar Internasional Pendidikan IPA ke-1 Spa. UPI Bandung.

Muslam, H. (2011). Globalisasi dalam Pendidikan (Desain Kurikumum yang Harus Dikembangkan Dalam Pendidikan di Era Globalisasi). Wahana Akademika, 12(3), 4-12.

Rizal, H. P., \& Danial, M. (2014). Pengaruh Model Pembelajaran Inkuiri Terhadap Keterampilan Generik Sains Siswa Kelas Xi Ipa Sma Negeri 1 Pangkajene Sidrap. BIOEDUKASI (Jurnal Pendidikan Biologi), 5(1). https://doi.org/https://doi.org/10.24127/bioeduk asi.v5i1.249

Wirjosoemarto, K. (2004). Teknik Laboraorium. Jurusan Pendidikan Biologi FMIPA UPI. Bandung.

Yuliyanti, E., \& Hasan, M. (2016). Penguasaan Konsep Melalui Laboratorium Virtual. Jurnal Pendidikan Sains Indonesia, 4(2), 76-83.

Zainuddin, M. (2001). Praktikum. Universitas Terbuka. Jakarta. 